This item was submitted to Loughborough's Research Repository by the author.

Items in Figshare are protected by copyright, with all rights reserved, unless otherwise indicated.

\title{
Innovation with change: developing a community of practice to help teachers move beyond the 'honeymoon' of pedagogical renovation
}

PLEASE CITE THE PUBLISHED VERSION

http://dx.doi.org/10.1080/17408989.2013.817012

\section{PUBLISHER}

Taylor and Francis / @ Association for Physical Education

\section{VERSION}

AM (Accepted Manuscript)

\section{PUBLISHER STATEMENT}

This work is made available according to the conditions of the Creative Commons Attribution-NonCommercialNoDerivatives 4.0 International (CC BY-NC-ND 4.0) licence. Full details of this licence are available at: https://creativecommons.org/licenses/by-nc-nd/4.0/

\section{LICENCE}

CC BY-NC-ND 4.0

\section{REPOSITORY RECORD}

Goodyear, Victoria A., and Ashley Casey. 2019. "Innovation with Change: Developing a Community of Practice to Help Teachers Move Beyond the 'honeymoon' of Pedagogical Renovation". figshare. https://hdl.handle.net/2134/19546. 
Innovation with change: developing a community of practice to help teachers move beyond the 'honeymoon' of pedagogical renovation

Victoria A Goodyear and Ashley Casey

Institute of Sport and Physical Activity Research, University of Bedfordshire, UK.

Corresponding Author:

Victoria A Goodyear, University of Bedfordshire, Polhill Avenue, Bedford, Bedfordshire, MK41 9EA, UK

Email: Vicky.Goodyear@beds.ac.uk 


\section{Innovation with change: developing communities of practice to help teachers move beyond the 'honeymoon' of pedagogical renovation}

\section{Structured Abstract}

Background: Physical education has long been caught in a time of 'innovation without change'. Yet, despite a wealth of pedagogical innovations and policies, which encourage a reconsideration of the 'traditional pedagogy', teachers rarely move beyond the honeymoon period of implementation.

Purpose: The purpose of this paper is to explore how communities of practice emerge, develop and support innovation that results in pedagogical change.

Participants and Setting: Six secondary school teachers from a comprehensive secondary school in the UK used the Cooperative Learning model, which was identified as the pedagogical innovation, to teach physical education for a minimum of four units of activity (6-8 lessons each). Teachers were supported by a researcher who acted as a boundary spanner.

Research Design: To support their understanding and use of Cooperative Learning the teachers' engaged with action research through a) the analysis of their observations and reflections, b) dialogue with the boundary spanner and colleagues, and c) negotiation with their students. Multiple sources of data informed the study including: teacher reflections, a field journal, a Verification Tool, interviews, teacher observations, professional learning meetings, and discussions on social media.

Data Analysis: Data were analysed through constant comparison, inductive analysis and peer examination.

Findings: The boundary spanner was a catalyst for the adoption and sustained use of pedagogical innovation, facilitating teachers' use of action research, driving social energy, and the subsequent emergence of a community of practice.

Conclusion: If physical education is to move beyond the traditional pedagogies, then communities of practice are a professional learning strategy that can support pedagogical innovation with change, especially when boundary spanners help to get them started.

Keywords: Action Research, Communities of Practice, Pedagogical change, Innovation, Cooperative Learning. 


\section{Introduction}

Great ambition, the desire of real superiority, of leading and directing, seems to be altogether peculiar to man, and speech is the great instrument of ambition (Smith, 1759)

In his treatise on ethics the philosopher and economist Adam Smith suggested that the 'podium' seemed to be a natural place for those who wished to lead and direct. Taking this observation forwards it has been argued that education is not the exception, in favouring the podium as the natural position for the teacher, but the rule (Dewey, 1929). Nothing seems more telling in this argument than the origins of the word 'lecture'. Drawn from the Latin Lect (read, chosen), the word represents the medieval academic tradition of reading from original sources and notes, and has come to represent a notion of schooling centred on the one-way conveyance of information from expert to novice. The term has also come to mean "a long serious speech, especially one given as a scolding or reprimand" (Oxford English Dictionary). The irony of this dual definition is such that 'lecture-style' delivery has been heavily criticised by exponents of critical pedagogy and yet the 'lecture' has remained the mainstay of educational practice for hundreds of years.

In physical education the dominant practice of lecturing from the front of the class has not been significantly altered since the days of the drill sergeant in the late $19^{\text {th }}$ Century (Kirk, 2010; Tinning, 2010, 2012). Indeed, such a militaristic, teacher-led 'doas-I-do’ (Casey, 2010) approach has, for more than a century, been the key means through which schools and teachers have managed, organised, manipulated and ‘schooled children’s bodies’ to produce members of an orderly society (Kirk, 1999). Such an approach to teaching holds little relevance to young people in the $21^{\text {st }}$ century and perhaps should be regarded as an obsolete means for learners to explore the sociocultural significance of human movement (Tinning, 2010, 2012). Drawing upon the lack 
of dichotomy between past and current practice, Kirk (2010, 2012) recently cautioned that unless a pedagogical change can firstly pervade and secondly survive in teachers' classroom practices, then physical education may no longer hold a legitimized place in education and could become extinct. It is against this background that this investigation is set. At this juncture it is worth noting that this paper is nested within a longitudinal study exploring pedagogical change, and addresses one research question from the overarching project i.e. how do teachers' learn to use a pedagogical innovation within and beyond their initial experiences?

In his discussions about pedagogy, Evans (1985) suggested that we live in a time of "innovation without change" - a point that we reiterate now. Whilst a number of alternatives have been proposed to help practitioners use alternatives to the 'traditional pedagogy' (from Mosston’s spectrum, and Maulden and Redfern’s reconsideration of games teaching in the 60s, through Sport Education and Teaching Games for Understanding in the 80s, and curriculum, instructional, and pedagogical models in the early part of this century and beyond), coupled with the introduction of policies which sought to promote innovative practice and high quality teaching and learning (Flintoff, Cooke and Squires, 2006; Kirk, 2010, 2012), the teacher-led approach has remained ‘THE way to teach’ physical education (Tinning, 2010, 42). Casey (2012a) held that although teachers demonstrate a willingness to use pedagogical alternatives they rarely move beyond the initial point of implementation (or honeymoon period). In this regard, pedagogical innovations, policies and strategies have failed to unsettle the do-as-I-do approach (Kirk, 2010, 2012; Tinning, 2010, 2012).

Despite this period of innovation without change, shifting the expectations around teaching and learning in physical education is not easy, for change lies not only in the desire of the teacher to change but also in the extraneous expectations about the subject, 
especially what it does and how it does it (Bechtel and O’Sullivan, 2006; Casey, 2012b; McCaughtry, 2006). Flintoff et al. (2006, 5) argued that no curriculum reform would be significantly useful in promoting better practice without mechanisms "to help teachers critique the nature and relevance of their practice to today's students”. Indeed a number of authors claim that teacher change is evidence-bound, where a shift in teachers' beliefs and practice is often dependent on teachers' understanding of their students' responses to their pedagogy (Armour and Yelling, 2007; Deglau and O’Sullivan, 2006; Patton and Griffin, 2008). Thereby, it seems reasonable to suggest that in order to create innovation with change a reconceptualization of teacher professional learning is required (Armour, 2010; Armour and Yelling, 2007; Casey, 2012a; Kirk, 2010).

\section{Professional Learning}

In physical education a number of curriculum theorists have called for teachers to work together in communities of practice (CoP) with university/teacher collaboration to aid pedagogical change (Armour and Yelling, 2007; Casey, 2012a; Deglau and O’Sullivan, 2006; Harvey and Jarrett, 2013; O’Sullivan, 2007; Patton et al. 2005; Parker et al. 2010). Quite often in a CoP, teachers work together to inquire into their respective practices and to develop their understanding of how to use a new pedagogical approach (Atencio, Jess and Dewar, 2012; Calderón, 1999; McLaughlin and Zarrow, 2001). A CoP creates 'space' for meaningful, worthwhile and frequent discussions between teachers, which in turn facilitate the development of their own and others’ pedagogy (Calderón, 1999; Deglau and O’Sullivan, 2006; Parker et al. 2010; O’Sullivan, 2007). Parker et al. (2010) suggested that this method of professional learning broke down feelings of isolation, which empowered teachers to discuss their own practice and support their colleagues’ learning. Importantly, through participation in a community teachers have developed a deeper understanding of their practice and in some cases the use of a pedagogical 
innovation has been sustained (Calderón, 1999; Deglau and O’Sullivan, 2006;

O’Donovan, MacPhail and Kirk, 2010, 2012).

Despite the reported effectiveness of CoP, they are under-developed in physical education (Harvey and Jarrett, 2013; O’Sullivan, 2007). Whilst there is encouragement for the use of CoP there is a paucity of research that explores how they develop and their ability to support pedagogical innovation with change (O’Sullivan, 2007; Parker et al. 2010). In this paper we suggest pedagogical innovation with change is possible when teachers are supported in their inquiries and encouraged to engage in dialogue with other teachers within, and beyond, the honeymoon period of innovation. Therefore, the purpose of this paper is to explore how a CoP began to emerge and how its emergence subsequently supported pedagogical innovation that results in change.

\section{Communities of Practice}

The idea of a CoP is attributed to the seminal work of Lave and Wenger (1991) and their theoretical perspective of situated learning (Hoadley, 2012). A CoP could be summarised as a group of people who "deepen their knowledge and expertise in [an] area by interacting with one another on an on-going basis” (Wenger, et al. 2002, 4). The assumption is that "learning is an integral and inseparable aspect of social practice" (Lave and Wenger, 1991, 31) where a person is not seen as an individual but part of a cultural and community context (Fleer, 2003; Lave and Wenger, 1991; Wenger, 1998a). Wenger (1988a) suggests a CoP is a group of people who hold three dimensions: mutual engagement, a joint enterprise and a shared repertoire. In this way, CoPs exist because each participant occupies a unique identity where their contributions are important for other members (mutual engagement). Members facilitate the development of each other's practice, and the practice of the community, in order to achieve a common and negotiated 
goal (joint enterprise). Over time the community develops routines, actions, or ways of doing things that become a sustainable part of their practice (shared repertoire).

Communities can take many forms, such as knowledge-building communities, learner communities or teacher communities (Barab and Duffy, 2012). Building on the work of Lave and Wenger (1991) and Wenger (1998a), Hoadley (2012) suggested that a CoP has distinct features which contrast against these other notions of communities. Firstly, a CoP has a degree of informality (Hoadley, 2012). By this means, a CoP is not simply an organization or a group of people who work for an organization (Hoadley, 2012). Instead, a CoP has a low level of institutionalization where it sets its own agenda(s) and establishes its own leadership. A CoP can exist within an organizational structure, such as a school, and in doing so it can strengthen the outcomes or goals of the organisation (Hoadley, 2012; Wenger, 1998b). Secondly, Hoadley (2012) held that a CoP has a high level of connectivity. In other words, the community holds a tight social network while offering a high degree of individual identification within the community (Hoadley, 2012; Wenger, 1998b).

Although the notion of CoP was foregrounded by Lave and Wenger (1991), their conception is based upon an anthropological perspective, examining CoP in everyday society and not environments intentionally designed to support learning (Barab and Duffy, 2012; Hoadley, 2012). Indeed, Hoadley (2012) suggests that there has been a shift in the way of thinking about CoP from one which naturally occurs to one where a CoP can be supported and fostered to situate learning in an authentic context. Whilst Wenger (1998b) suggests that members may have a tacit way of knowing they are connected to others, and are an insider in a collective group of individuals who can help nurture their development, it has been suggested that CoPs emerge from individuals working together for a particular purpose (Barab and Duffy, 2012; Fleer, 2003). The difference between a 
naturally occurring community and a community which is fostered, is that naturally occurring communities do not have pre-defined learning goals (Barab and Duffy, 2012; Hoadley, 2012). Yet importantly a CoP cannot be created. Instead, communities must have some form of history for them to emerge from, and members must share a form of history with one another (Barab and Duffy, 2012; Hoadley, 2012). In this way CoP take time to develop. However, technology and social networking sites can support communication and can be used to begin to connect people and allow members of an emerging CoP to understand that they share commonality with each other (Hoadley, 2012). Moreover, having access to an expert or a facilitator who arranges time for professional dialogue, supports individual and community inquiry and empowers individuals to have a voice and ownership over pedagogical change can foster the emergence of a CoP (Calderón, 1999; Goodnough, 2010; Hoadley, 2012; McClaughlin and Zarrow, 2001; O’Sullivan, 2007; Parker et al. 2010). Thereby, it seems reasonable to suggest that a CoP can emerge from within a school, if a collective group of individuals have a shared purpose or learning goal (in this case the use of an innovation) and their connectivity with each other are fostered.

\section{Methods}

\section{Participants and Setting}

A physical education department consisting of six (3 male, 3 female) qualified physical education teachers of mixed experience ( $<1$ and $>15$ years) from a co-educational comprehensive secondary school (age 11-19) in England participated in the study. The school's students were predominantly from white middle class backgrounds, few had English as an additional language and the proportion of students with special educational needs or disabilities was below the UK National average.

The first author (Victoria), who had experience of teaching physical education 
through Cooperative Learning and using practitioner inquiry as a teacher, acted as the 'boundary spanner'. However it is important to note that she was not a teacher at the time of this study. The term boundary spanner is derived from the work on organisational structures by Thompson (1962) and later Aldrich and Herker (1977). These authors argued a boundary spanner distributes information, filters information and facilitates the use of information in different organizations (Aldrich and Herker, 1977; Thompson, 1962). By this means, the boundary spanner is a representative of an organisation and acts to meet their organizations goals by distributing the service or product through interacting with other agents in society (Aldrich and Herker, 1977; Thompson, 1962). We use the term boundary spanner to signify that Victoria was someone from a different professional organisation (a university in this case) who brought in new information and supported teacher inquiry.

\section{The pedagogical innovation}

The Cooperative Learning model (c.f. Dyson and Casey, 2012) is positioned as the pedagogical innovation since, although five out of the six teachers had previous experience of using other pedagogical models (but not beyond the honeymoon period), none of the teachers had used Cooperative Learning prior to this study. The study began with three month period of professional development, to improve the teachers' use of action research, and to develop their understanding of how to use Cooperative Learning to teach physical education (Goodyear, 2013a). Following the professional development programme the teachers used Cooperative Learning to teach a minimum of four different units (six-eight lessons) during an academic year to a minimum of one class on their timetable. The classes chosen by the teachers to participate in this study were all single sex and ranged from year 7 (age 11-12) to year 10 (age 14-15). 
The research design was practitioner inquiry through participatory action research. The teachers engaged with the three key features of action research extolled by Ax, Ponte and Brouwer (2008): analysis, dialogue and negotiation. Analysis occurred through the observations of their students' learning and the reflections on their practice. Dialogue, with each other, and Victoria, either face-to-face or through the online community discussion board (Physical Education Practitioner Research Network). Negotiation occurred with focus groups of the students they taught.

Victoria's role throughout the study was multi-faceted and included being a critical friend, facilitator, supporter, and researcher (Goodnough, 2010). She observed the first lessons and last lessons of each unit taught (by every teacher) and some additional lessons when she visited the school to see other teachers. 63 lessons were observed in total. She also conducted pre- and post-lesson, and unit interviews with all six teachers. The interviews were semi-structured and used the Sunday Afternoon Drive Model (Sutherland, 2012) which uses the fundamental questions of "what happened", "so what", and "what now" (Sutherland, 2012) to inform current and future practice. On average Victoria visited bi-weekly.

\section{Data Gathering}

As this paper is nested within a longitudinal project multiple sources of data informed this study. The data gathering tools are represented and explained in table 1 . It is important to acknowledge that social media was an emergent, and unpredicted data source. Data was gathered from 49 private message through Facebook and 76 conversations (defined as two tweets or more) through Twitter over the course of the academic year between the teachers and Victoria. There were 125 separate conversations on social media over 203 days (including weekends and holidays) that involved five of the teachers. Their preferred time for contact varied but the conversations often occurred 
when Victoria had not seen the teachers for a period of time or in response to Victoria's tweets or status updates (on both Facebook and Twitter).

[Insert table 1 here]

\section{Data Analysis and Trustworthiness}

Inductive analysis and constant comparison were used to analyse the data (Lincoln and Guba 1985). The process started with the analysis of the video recorded lessons using the Validation Tool and the transcription of interviews and teachers' reflections. Once this was complete Victoria approached the data through an inductive lens. In Morse’s (1994) terms she began comprehending the data by reading the texts and writing analytical memos. The analytical memos allowed her to reflect, document her understandings and maintain a level of reflexivity in the analytical process (Phillips and Carr, 2007). Once these processes were complete descriptive codes were developed and then used to identify and group interesting statements and events from all data sources. For example, some of the codes included: working together, student impact and informal and formal discussions. This formed the first-order of analysis, which as a result produced thematic descriptions of the key features that supported teachers' use of the pedagogical model, and the factors that motivated them to continue to use the model. The themes identified from this process were, support from the researcher, learning communities and evidence of effectiveness (Goodyear, Casey and Kirk, 2012).

The second stage of the analysis was undertaken to increase the validity of the findings. In keeping with the work of Gall, Borg and Gall (1996), and Merriam (1995), the peer examination strategy was used to member check and pass comment on how items were coded, categories were defined and findings were developed. To achieve this the second author independently reviewed the overarching content themes that had emerged, in addition to analysing samples of data, to determine if they had been placed in 
appropriate categories. When the analysis from both researchers was compared no major discrepancies were found. However, whilst the first author had considered the conceptual links between these themes in accordance with constant comparison and inductive analysis (Lincoln and Guba, 1985), the second author identified that further consideration of the relationship between them was needed. Furthermore, the second author challenged the themes and their interrelation with the CoP literature. In this way we sought to ensure the data had theoretical sensitivity since we had identified that without the wider consideration of $\mathrm{CoP}$ the themes represented mundane descriptions of the data (Charmanaz, 2008).

The third phase of analysis involved the reconceptualization of the original themes to explore the relationship between them and their connection with the literature on CoP. The two authors discussed the original themes and pinpointed on a timeline when the original themes were most prominent within the four units taught and subsequently, how these themes were then related to the dimensions of a CoP (Wenger, 1998a). Whilst the analysis began inductively we later transferred to a deductive approach to understand how a CoP emerged and supported pedagogical innovation with change. Four themes were subsequently identified: 'sustained support from the boundary spanner,' 'dialogue, analysis and negotiation,' 'dialogue with each other' and 'the departmental approach.’

\section{Results}

This section explores how a CoP began to emerge and how this emergent community developed and supported pedagogical change beyond the honeymoon period. In accordance with reports that creating change in schools is a timely and messy process (Atencio et al. 2012; Patton and Parker, 2012), we argue that the first manifestation of this CoP took the better part of six months to emerge. It was only at this point, and 
beyond the anticipated point of this study, that the social framework was capable of supporting the teachers' use of the innovation. Yet the very emergence of the CoP was dependent on the boundary spanner, who supported and encouraged teacher learning. The first theme, 'sustained support from the boundary spanner', is an overarching theme that explores the pivotal role Victoria played throughout in fostering the emergence of a CoP and pedagogical innovation with change. In the second and third themes, 'dialogue, analysis and negotiation' (Ax et al. 2008) and 'dialogue with each other' we explore how the boundary spanner and teachers' use of participatory action research facilitated teachers understanding of their practice, afforded them the opportunity to explore the commonalities that they had with one other, and how as a department their collective use of an innovation was situated within their organisational boundary i.e. the school. The final theme, 'the departmental approach', suggests that a CoP was emerging and through mutual engagement, a shared repertoire and a joint enterprise, teachers' use of the pedagogical innovation was supported.

\section{Sustained support from the boundary spanner}

To enhance teachers' ability to use innovations it has been acknowledged that an outsider can facilitate the process of teacher change (Parker et al. 2010; Patton and Griffin, 2008; Patton and Parker, 2012; Patton et al. 2005). We argue that the main catalyst for change, and the emergence of the CoP, was 'the boundary spanner'. Accordingly, we feel it is important to embody her role within the process of pedagogical innovation with change.

Throughout the four, five or six units taught, Victoria facilitated teachers' engagement with the model through both formal and informal conversations. In response to their immediate reflections, she helped to develop the teachers' understanding, through the post-lesson interviews, of their own and each other's practice, and helped them to 
gain insights into their students' learning. The informal conversations that took place in the staff room, in the department office, or through social media, only began once teachers had engaged with an extended contemplation of their use of the model. On most occasions the teachers initiated these conversations and, in the main, they appeared simply to want someone else to talk to about their units or lessons, or to ask questions. A significant advantage of using social media in this study was that the teachers had regular support - most particularly from Victoria. Theses interactions often occurred when she had not visited the school or seen the teachers over a period of time.

Twitter and Facebook have proven an effective way for me to communicate with teachers this week... For instance, Miss Scholes and Miss Collie spoke to me on Friday night about how their lessons went. Mr Minns spoke to me on a Thursday night about how the rain was affecting his lessons and what he could do in terms of resources....Miss Keeping contacted me through Twitter on Sunday night about what she could do in the next unit. (FJ Unit 1)

In this 'virtual space’ Victoria reassured teachers, challenged their reflections, gave them ideas, and encouraged them to use the insights they gathered from their use of action research. The following twitter discussion is an example of how this occurred.

@ Miss Keeping: massive ownership being seen by pupils now within my CL lessons @Victoria: really interesting!!! Down to all the hard work and planning u have put in:;

@Miss Keeping: think it's more on the pupils understanding and now they have choice on roles and responsibilities instead of me choosing them @Victoria: what's your next challenge for them @Miss Keeping: not too sure at this point something I need to think over. Suggestions?

@Victoria: see after next week if there are any themes in your reflections before next unit - team comps may challenge socially further (Twitter Conversation 26.4.12)

However, whilst some teachers still preferred face-to-face dialogue with Victoria (such as Mr White, the most experienced teacher, who only spoke with Victoria once through Facebook) social media served as available platform if they chose to use it. Considering Victoria's facilitation further, some teachers preferred support from her 
rather than their colleagues. For example, although towards the end of the study Miss Collie began to share her resources and discuss her practice with her colleagues, she preferred to talk to Victoria about her actual practice and the decisions she might make. However, regardless of whether the teachers discussed ideas with each other or with other teachers in their school, it was the year-long support from Victoria that they saw as important. All teachers reported that the "constant dipping in and topping up of Cooperative Learning skills” (Mr White YE Interview) enhanced their understanding of how to use the model and gave them a form of moral support.

Victoria engaged with the teachers in their classes, the physical education department, and their 'virtual worlds'. As we discuss in the following themes, in these contexts, she brought in new information, facilitated practitioner inquiry, initiated professional dialogue between teachers, and subsequently provided a 'scaffold' for getting this CoP started (McLaughlin and Zarrow, 2001; O’Sullivan, 2007; Tannehill, 2011). Moreover, through the juxtaposition of the virtual and the real worlds, she developed a trusted and supportive relationship where teachers felt comfortable to confide in her and seek her advice. Therefore, she played a vital role in encouraging and developing teachers' understanding that professional learning needs to be situated, but also that learning does not only occur in a ‘workshop' or professional development course. The support she provided in spanning the boundary between theory and practice was sustained, frequent and easily accessible, which we suggest facilitated the teachers' pedagogical understanding of the impact of the model, the dialogue between one other, and was the foundation of the emerging CoP. Yet this was not a simple or straightforward process and the next three sub-sections of the paper will explore how Victoria supported teacher learning and the emergence of the CoP.

\section{Dialogue, Analysis and Negotiation}


Following the professional learning programme there was a 'buy in' by the teachers, seen through their willingness to use the innovation (McCaughtry et al. 2004, p.137). Yet there is a strong indication in both the professional development literature (Armour and Yelling, 2007; Deglau and O’Sullivan, 2006; Patton and Griffin, 2008), and the models-based practice literature (Casey, 2012a) that teacher change is evidencebound. This was certainly the case in this study, as before teachers could 'accept' the model as something which could be a 'permanent fixture' in their practice, and before they reflected on and supported their colleagues' use of the model, they needed to determine whether it had impact on their students’ learning. However, the teachers did not always seek evidence themselves. The gathering of evidence, which encouraged them to move beyond their initial use of the model, often fell to Victoria. For example, the teachers questioned whether their use of the model was more beneficial than their teacher-led approach. Mr Churchward reflected, “he [indicating a student] is making improvements, he [indicating another student] is not making as many improvements to his technique...would it be any different if I was teaching him as like I normally would?” (PL Interview, Unit 1). Victoria helped the teachers to reflect and provided interview questions for them to explore their students’ learning and develop an understanding of the impact of their innovative pedagogy.

In the first and second unit, post lesson interviews with Victoria were often where teachers expressed their concerns about the impact of the model on students' learning. These interviews were an important time for Victoria to further teachers' understanding of the model and encourage them to reconsider their immediate thoughts on students' learning. For example, Miss Scholes said: “it’s really hard because I wanted them to do all three fitness tests... it was better than I thought it would be but not as good as if I was leading it myself” (PL Interview, Unit 1). Following the description of events (“what 
happened?” (Sutherland, 2012)), Victoria would question the teachers on their aims and objectives for the lesson and try to focus their attention on what they were trying to achieve (“so what?” Sutherland, 2012). In response to Victoria’s questioning the teachers began to better understand the impact of their changing pedagogies and could consider the wider aspects of their students' learning and how this could transfer into subsequent lessons ("what now?” Sutherland, 2012)). At the end of an interview, in which she expressed her frustration with her students' lack of physical competence in the lesson, Miss Scholes came to the conclusion that "they [the students] probably got more from it because they know what they are doing now because they had to learn how to do the test and in fact the second test they did I had to have little input in” (PL Interview, Unit 1). It is clear from these discussions that Victoria played a primary role in facilitating teachers' understanding of their students' learning and in challenging their beliefs that learning can only occur in the physical domain as most likely seen in their do-as-I-do approach. Instead, the teachers came to see that learning could occur in multiple domains when certain pedagogical decisions were made and then enacted.

The student focus group interviews also helped to develop teachers' understanding of their students' conceptions of learning. Victoria had provided the teachers with sample questions to use in these interviews, but the teachers began to ask additional questions in order to understand their practice from their students’ perspectives.

Mr White: So do you think your skills have improved?

Rick: I think I have improved quite a lot actually, especially in trampolining, because before my seat drop wasn't very good but now I think I am actually quite good at it

Mr White: So do you think that is a result of how you were taught in the lesson i.e. teaching each other?

Rick: yeah (sic.)....I think I have learnt that we work better in groups and that working in groups is sometimes better than the teacher, because the teacher can tell you what to do, but then working in groups you can have different ideas from different people 
(U1 FG Interview)

The confirmation from students that they were learning, and that they enjoyed this way of learning, coupled with Victoria’s discussions re-enforcing learning in multiple domains, went some way to encouraging the teachers to move beyond their initial use of the model. For example, when Victoria asked Mr White what the most positive thing about the unit was, he responded:

Listening to the students and them saying that they enjoyed that method of delivery as opposed to what they had experienced of PE in the past. Not necessarily with me as such, but their experience of PE has always been teacher leads the practice, teacher leads the differentiation, teacher leads the progress and the next steps, whereas what they found, and what they enjoyed was that they liked having that ownership and deciding where the lesson went next and they liked that approach as well (U1 Interview).

The teachers also analysed students' learning in their Cooperative Learning lessons compared with others taught through do-as-I-do. For example, Mr Churchward compared his year seven (age 11-12) classes. At the end of the year he commented:

"The amount of progress was probably as good and if not better as when I did the old school teacher led approach...if this style of learning is going to create an improved progression rate in the pupils, then surely you should use this over traditional methods” (YE Interview).

By talking with Victoria, negotiation with students in focus groups, and the analysis of students' learning in Cooperative Learning and in their do-as-I-do approach, the teachers developed an understanding that their use of the model was a 'success' in terms of student responses, learning and motivation. As a result the teachers were motivated to continue using the model.

“If it hadn't of been a success you wouldn't want to continue with it, but I have had success with two groups...you try little things out and you see that the kids respond quite well to it.” (Miss Keeping, YE Interview).

\section{Dialogue with each other}


Whilst the teachers investigated their students’ responses to the model in the first and second units, they were very reluctant to discuss their teaching with other teachers in their department. Although they knew that other teachers were teaching through the model 'they didn’t know the ins and outs' (FJ, Unit 2). In the following section we discuss how the department began to share their experiences with each other during the later units without encouragement from Victoria. Although we cannot be certain, and our interpretations are based upon ontological assumptions of sequential events, the professional learning meetings initiated by Victoria, the in-school recognition for their innovative use of Cooperative Learning and a sense of competence which occurred following the first unit, facilitated dialogue between the teachers where little or none had occurred before.

Towards the end of unit one and during unit two, Victoria deliberately began to facilitate discussions between teachers by posting questions to the web-based forum. However, the teachers rarely contributed to the web chats and suggested that time was an inhibiting factor. During the third unit, Victoria sought to encourage further dialogue between teachers through 'professional learning meetings'. In contrast to the web-based forum, when teachers were face-to-face in the professional learning meetings discussions with one another took place. Based on Victoria's observations of each teacher's use of the model she encouraged them to open up a pedagogical dialogue with their colleagues as she felt that it would help them to further both their understanding of the model and their use of it. For example, she asked Miss Scholes to share how she had modified her use of group processing and this process was then repeated with each teacher.

Victoria: Miss Scholes found that when she was doing group processing Miss Scholes: 'it lasted thirty seconds

Victoria: yeah and it was really short....[looking at Miss Scholes] do you want to describe what you did?

Miss Scholes: I went back and I completely stopped the lesson and I think I spent a good 15-20 minutes on what I expect from group processing... 
(PL Meeting)

Victoria also undertook to write a piece for a professional journal with the teachers on their 'top tips for using Cooperative Learning to teach secondary school physical education’ (Goodyear, 2013b), and initiated a second meeting. When voicing common experiences through the 'top tips', the teachers learnt that their opinions of best practice showed significant commonality across the group. This in turn seemed to legitimized the ways that they were using the model and strengthened their belief that they were doing it 'right'.

Miss Scholes: depends on how good you are at doing open and closed questions, so you become more of a facilitator not someone who gives the answer to them, I think that can come with experience Mr Minns: yeah so start your questions how, why, if or how could you improve this

Mr Churchward: yeah or if you [also] put questions on your resource cards as a separate box then you don't even have to deliver them to the pupils. Rather than you having to interject and formally question you can enhance and deepen their discussions that have already begun Miss Keeping: yeah that is almost the thing that I did with progressive questions...

(PL Meeting)

Although the teachers did not talk to each other during their initial use of the model without prompting from Victoria, they did initiate discussions with teachers from other departments and senior leaders. These colleagues were not familiar with Cooperative Learning, yet as part of the organisational boundary of the school, the discussions with other teachers served to link the practices of the department to the wider context of the school. The teachers began to share what they were doing with colleagues external to the department and develop their colleagues understanding of how they might use of the model. Subsequently, their use of the model was praised and they gained recognition for their use of the pedagogical innovation and engagement with practitioner inquiry. 
When Mr Churchward explained the study in the school meeting, the deputy head said that the PE department are involved in a great study enhancing their teaching and learning and that staff should go down to the department and see what is going on... Moreover, the assistant head has shown some interest, Mr Minns has said that he is shocked and thinks it is excellent that he reflects on his lessons using the Dictaphone whilst he is on break time duty. (FJ, Unit 2).

At the end of unit two and during unit three the teachers also began to report that they felt more confident using the model. For example, Victoria noted at the end of the second unit: "teachers are beginning to also state that the [elements] are becoming more autonomous” (FJ, Unit 2). Furthermore, findings from the validation tool suggested that teachers' ability to use the model faithfully was beginning to become more consistent.

Thereby, through the process of analysis, negotiation and dialogue with the boundary spanner (as discussed in the previous section) the teachers had begun to accept the innovation as part of their own individual practice. Yet when they shared their practice with each other during professional learning meetings and by communicating their practice to school members they began to situate their practice within their department and as a collective group of individuals using the same pedagogical innovation within the school. Through this 'telling of stories', the teachers began to construct an identity as a member of a community which in turn supported the construction and development of what could be assumed as an emerging CoP (Barab and Duffy, 2012). Indeed, it could be suggested that the teachers began to see themselves as knowledgeable and skilful, and understand that they had shared practices and a shared history with one-another (Barab and Duffy, 2012; Wenger et al. 2002). Furthermore, and in keeping with Barab and Duffy (2012) and Wenger (1998a), situating their community within the larger community of school gave the practices of the community members meaning and purpose. Through colleague recognition, their use of an innovation as a collective group of individuals was celebrated from within the institution and, it could be argued, that the senior leaders saw their use of Cooperative Learning and practitioner 
inquiry as a facilitating factor for the school to meet their goals of enhancing teaching and learning. However, whilst the teachers began to share a collective practice, which was the innovation, in the following section we explore how mutual engagement, a shared repertoire and a joint enterprise was seen to emerge and support teachers' use of the pedagogical innovation during the fourth, fifth and sixth units taught.

\section{The Departmental Approach}

During the fourth unit, and for some teachers who chose to teach an additional fifth or sixth unit, a community-based approach to teaching through the model emerged. Discussions about the use of Cooperative Learning were more frequent and occurred without Victoria. In departmental meetings the model became one of the formal meeting minutes, where the teachers shared their experiences, their plans for the next units, and their resources. In her field notes Victoria observed informal discussions when the teachers walked back from the sports fields, when they were waiting for students to get changed and in the physical education office. The teachers also started to reflect in front of each other, asked each other how their lessons had gone, and gave moral support or suggestions for how lessons could be modified.

“There's always quite an open conversation about it and sharing of experience, if things didn't work you often came back and said it didn't work, or if someone had had a really bad lesson we would come back and laugh about it” (Miss Scholes YE Interview).

The most beneficial factor about working together was the sharing of lesson plans and resources. The teachers claimed that this allowed them to continue teaching through the model even when time was not available for them to plan and prepare resources. Moreover, they were able to build upon each other's experiences and develop new ideas. In his exit interview Mr Minns said "we shared resources and we shared good practice...I have used those that have been used in the past and vice versa...everyone has been really helpful”. Comparatively, Mr White recalled: 
"If I wanted to bounce ideas off of them about how did they do x how did they do $y$, because they were doing different strategies that helped me in evaluating the impact of what I was doing (YE Interview).

Whilst the institutional context can maintain the use of the teacher-centred approach and indeed hinder teachers' engagement with or use of alternative pedagogies (Tinning, 2012), the supportive climate created within the department allowed teachers to move beyond the school contextual factors which can inhibit innovation (Casey, 2012b; Ovens, Dyson and Smith, 2012; Patton and Griffin, 2008). In addition to supporting each other's practice through the sharing of resources, and subsequently reducing the planning and preparation time within the 'busyness of schools' (Casey, 2010), the teachers were willing to address the teacher and departmental performance culture within the school. In the UK, the Government and schools assess the quality of teaching and learning through an OfSTED criterion (Cale and Harris, 2009). During observations teachers are graded against OfSTED’s criteria: outstanding, good, satisfactory or unsatisfactory, which serves as an external measure of the observer's interpretation of good practice (Cale and Harris, 2009). During the fourth unit the department welcomed an internal assessment of their pedagogy, whilst at the same time risking a potential critique of the effectiveness of their newly adopted pedagogy when it was held up against the school's and OfSTED’s expectations (Calderón, 1999; Casey, 2012b). Victoria noted 'all the teachers seemed to be quite up for it, getting an external opinion of Cooperative Learning but to also see how it matches with OfSTED criteria' (FJ, Unit 4). It seemed the teachers needed to determine whether teaching through the model could meet these extraneous expectations and determine whether it had credence as an effective pedagogical approach in their school. The outcome of the assessment was that when members of the senior leadership team and Mr Churchward (director of physical education and also one of the six teachers) 
observed three teachers' use of the model they graded two as outstanding and one as good (with outstanding features).

Consequently, we suggest that through the recognition of outstanding teaching, coupled with the department's longer term view of enhanced student learning and engagement, the model was afforded currency in the inspection climate within the UK. The model's acknowledged ability to achieve 'outstanding' in its own right lent further credence to the teachers' identities as innovative practitioners. In other words, the accolade of 'outstanding' served as further 'proof' for the teachers, the department and the school that the model worked. Finally, in achieving 'outstanding' and 'good with outstanding features' these teachers' place in this emerging CoP was strengthened. The three teachers were seen to contribute to the community and validate its practices, and for the department this served to legitimize the model within the context of their school. Consequently, we argue that these events demonstrate to some degree the emergence of mutual engagement, joint enterprise and shared repertoire (Wenger, 1998a).

By the end of the academic year, most teachers suggested that the department's use of Cooperative Learning was a facilitating factor in their own use and development of the model. They viewed the model as a longer term commitment for both their practice and the department which would involve the development of a central resource in which to share ideas and develop their practice. In this way, their continued use of the model would be aided by working together to support each other's practice, and not through the intervention of the boundary spanner - at least not to anywhere near the same degree.

Victoria: were there any factors that helped you to teach through Cooperative Learning?

Mr Churchward: sharing resources, erm obviously the training we received, your input of how to develop the lessons and yeah generally the support and the discussions, discussing what happened in lessons, working as a team (YE Interview) 
Miss Scholes: Every unit now, people have gone off over the summer and we are redesigning our schemes of work... and we are having a Cooperative Learning box and people are giving example of what they could do and what [Cooperative Learning] structures they could use and what structures had been used in the past and then setting up a central resource for each of the sports through Cooperative Learning (YE Interview)

\section{Discussion}

Towards the end of the $20^{\text {th }}$ century Evans (1985) described physical education as having a discourse of 'innovation without change'. Three decades later, despite the wealth of pedagogical alternatives to the do-as-I do approach (Casey, 2010), the discourse of physical education has not changed (Kirk, 2010; Tinning, 2010, 2012). Many pedagogical alternatives have remained as innovations and teachers rarely move beyond the honeymoon period of implementation (Bechtel and O’Sullivan, 2006; Casey, 2012a). Casey (2012a) held that such was the depth of research around curriculum change that as a research community we needed to look beyond the "does it work" questions and look longer term. We suggest that pedagogical innovation with change is possible through the sustained support from a boundary spanner who facilitates teacher learning, encourages open dialogue (between members of a department, students and colleagues within the school) and subsequently aids the emergence of a CoP. These three levels of social interaction encouraged teachers to move beyond the honeymoon period to a position where the innovation was becoming a sustainable part of their on-going and future practice. Furthermore, authentic interaction and discussion supported the teachers' willingness to make changes, and helped them develop the skills needed to use a pedagogical innovation. All this occurred, we would argue, despite the school contextual factors which have been shown to hinder innovation (Casey, 2012b; Ovens et al. 2012; Patton and Griffin, 2008).

The underlying purpose of this paper was to explore how a CoP emerged and subsequently how it supported pedagogical change. Through teacher inquiry we argue 
that the teachers developed an understanding that the pedagogical innovation 'worked' i.e. it had more impact than their previous pedagogical approach, which in turn allowed them to look 'longer term’ and begin to conceptualize Cooperative Learning as something more than a one-off. However, the impact of practice on students' learning, students' responses to the model, recognition for the teachers' use of a model, and teachers' feelings of competence to teach through the model need to be facilitated before teachers were willing to, (a) move beyond the honeymoon period, and (b) autonomously engage in professional dialogue with one other. For example, the boundary spanner needed to empower the teachers to have a voice and create 'space', 'time', and a 'format' in which the 'telling of stories' could occur (Barab \& Duffy, 2012). Subsequently, we consider that where 'space' and ‘time’ were created, i.e. professional learning meetings, the teachers began to construct an identity as a member of a community. Furthermore, situating their use of the innovation within the department and the school we suggest were the means for the emergence of a CoP. In this way, whilst CoP take time to emerge (since members need to develop a shared history with one-another and understand how their practices are connected (Barab and Duffy, 2012; Hoadley, 2012; Lave and Wenger, 1991; Wenger, 1998a, 1998b)) the boundary spanner, by filtering information and supporting participatory action research, ‘speeded up’ the process of developing this CoP. Indeed, it could be suggested that the department were not a naturally occurring community, as Lave and Wenger (1991) perspective suggests, but that the boundary spanner fostered the creation of a CoP within the school for the purpose of enhancing the teachers' use of Cooperative Learning.

We suggest that as result of the connections with one-another and an understanding of their shared history, the dimensions of mutual engagement, shared repertoire and joint enterprise (Wenger, 1998a) became evident in the department during 
the fourth, fifth and sixth units. Through these three dimensions we argue that the teachers were encouraged to move beyond the honeymoon period. Furthermore, since Wenger's (1998a) three dimensions have been shown to develop in the final phase of the study (i.e. in the fourth unit and beyond) we believe this has also allowed us to tentatively explore how CoP benefit a teacher’s pedagogy. We consider that one of the most important beneficial aspects of teachers being a member of an emerging CoP might be their ability, both as individuals and as a department, to overcome the school's contextual factors that can impede teachers' use of pedagogical models, and indeed a novel curricular (Casey, 2012b; Ovens et al. 2012; Patton and Griffin, 2008).

An advantage of developing a $\mathrm{CoP}$ is that there is an increased likelihood that a pedagogical innovation will become a sustainable form of teachers’ practice (Calderón, 1999; O’Donovan et al. 2010, 2012). Teachers that organise time for professional discussions are more likely to continue to develop their understanding and use of a pedagogical innovation even when in-service professional learning, such as provided by a boundary spanner, is removed (Calderón, 1999). In contrast, without a supportive environment and teachers working together the likelihood that a pedagogical innovation will fall apart is greater (Calderón, 1999). In this way, we suggest that there is a greater chance that the pedagogical innovation, Cooperative Learning, will become an innovation with change.

Approaches that facilitate pedagogical change have not been evident, or indeed have not been capable of encouraging teachers to move beyond the honeymoon period of implementation (Casey, 2012a). This research led us to support previous calls for interprofessional collaboration with researcher(s) who cross the boundary of their institutions and engage in the milieu of physical education departments to facilitate change and the use of pedagogical models (Casey, 2012a; O’Sullivan, 2007). Whilst we acknowledge 
that 'innovation with change' through pedagogical models can happen without the support of a boundary spanner (Casey, 2010), we suggest that if researchers cross the boundaries of their institutions then as a profession we can increase the chances of pedagogical innovation with change. Indeed, it can be anticipated from these findings that, through her commitment to developing teachers’ practice and the social framework, the boundary spanner helped the teachers' sustain their use of the model well beyond the honeymoon period of implementation. Thereby, if physical education is to move beyond the tradition of do-as-I-do and help teachers' pedagogies to reflect the needs of the $21^{\text {st }}$ century, then this study has gone some way to confirming that CoP are a professional learning strategy that 'works' when boundary spanners get them started and help to sustain them.

\section{Acknowledgements:}

We would like to thank the reviewers for their helpful comments on the article, the physical education department at the Buckingham School and the Alexander Trust for their support with this study. Particularly we would like to thank David Kirk, Kim Oliver, Mikael Quennerstedt and Marie Öhman for their constructive comments and recommendations on previous drafts of this article. The authors are responsible for any shortcomings that remain.

\section{References}

Aldrich, H., and D. Herker. 1977. Boundary spanning roles and organizational structure. Academy of Management Review 2: 217-230.

Armour, K.M. 2010. The physical education profession and its professional responsibility...or...why '12 weeks paid holiday’ will never be enough. Physical Education and Sport Pedagogy 15 (1): 1-13. 
Armour, K., and M. Yelling. 2007. Effective professional development for physical education teachers: The role of informal, collaborative learning. Journal of Teaching in Physical Education 26: 177-200.

Atencio, M., M. Jess, and K. Dewar. 2012. 'It is a case of changing your thought processes, the way you actually teach’: implementing a complex professional learning agenda in Scottish physical education. Physical Education and Sport Pedagogy 17 (2): 127-144.

Ax, J., P. Ponte, and N. Brouwer. 2008. Action research in initial teacher education: an explorative study. Educational Action Research 16 (1): 55-72.

Barab, S.A., and T. Duffy. 2012. From practice fields to communities of practice. In Theoretical foundations of learning environments (second edn.), eds. D. Jonassen and, S. Lund, 29-65. New York: Routledge.

Bechtel, P.A., and M. O’Sullivan. 2006. Effective professional development- what we now know. Journal of Teaching in Physical Education 25: 363-378.

Calderón, M. 1999. Teachers Learning communities for cooperation in diverse settings. Theory into Practice 38 (2): 94-99.

Cale, L., and J. Harris. 2009. Ofsted - 'brief encounters of a second kind'?!. Physical Education and Sport Pedagogy 14 (1): 41-58.

Casey, A. 2010. Practitioner Research in Physical Education: Teacher transformation through pedagogical and curricular change. Unpublished PhD thesis, Leeds Metropolitan University.

Casey, A. 2012a. Models-based practice: great white hope or white elephant?. Physical Education and Sport Pedagogy IFirst Article. DOI:

10.1080/17408989.2012.726977 
Casey, A. 2012b. A self-study using action research: changing site expectations and practice stereotypes. Educational Action Research 20 (2): 219-232.

Casey, A., V.A. Goodyear, and B. Dyson. In Review. Using 'model provenance' to authenticate learning in and through Cooperative Learning.

Charmaz, K. 2008. Grounded theory in the 21st century: applications for advancing social justice studies. In Strategies of qualitative inquiry, eds. N.K. Denzin, and Y.S. Lincoln, 203-242. Thousand Oaks: Sage.

Deglau, D., and M. O’Sullivan. 2006. Chapter 3: The Effects of a Long-Term Professional Development Program on the Beliefs and Practices of Experienced Teachers. Journal of Teaching in Physical Education 25: 379-396.

Dewey, J. 1929. The source of a science of education. USA: Martino Publishing.

Dyson, B. 1994. A case study of two alternative elementary physical education programs. Unpublished Doctoral Dissertation, Ohio State University.

Dyson, B., and A. Casey. 2012. Cooperative Learning in physical education: a research based approach. London: Routledge.

Evans, J. (1985). Teaching in transition: the challenge of mixed ability groupings. England: Open University Press.

Fleer, M. 2003. Early Childhood Education as an Evolving ‘Community of Practice’ or as Lived 'Social Reproduction': researching the ‘taken-for-granted'. Contemporary Issues in Early Childhood 4 (1): 64-79.

Flintoff, A., B. Cooke, S.L. Squires. 2006. Evaluating high quality physical education and school sport - The challenge for teachers. Paper presented at the International Association of Physical Education in Higher Education (AIESEP), Jyvaskyla, Finland, July 5-8. 
Gall, M.D., W.R. Borg, and J.P. Gall. 1996. Educational Research: An introduction. 6th ed. London: Longman.

Goodnough, K. 2010. Teacher learning and collaborative action research: generating a "knowledge-of-practice” in the context of science education. Journal of Science Teacher Education 21: 917-935.

Goodyear, V.A. 2013a. Participatory action research: challenging the dominant practice architectures of physical education. Unpublished PhD thesis, University of Bedfordshire.

Goodyear, V.A. 2013b. Physical education teachers’ top tips on using Cooperative Learning to teach secondary school physical education. Physical Education Matters, 7 (2): 34-37.

Goodyear, V.A., A. Casey, and D. Kirk. 2012. Exploring the sustainability of the Cooperative Learning model. Paper presented at the British Educational Research Association Conference, Manchester, UK, September 4-6.

Harvey, S., and K. Jarrett. 2013. A review of the game centred approaches to teaching and coaching literature since 2006. Physical Education and Sport Pedagogy. DOI: 10.1080/17408989.2012.754005

Hoadley, C. 2012. What is a community of practice and how can we support it?. In Theoretical foundations of learning environments (second edn.), eds. D. Jonassen and, S. Lund, 286-300. New York: Routledge.

Kirk, D. 2012. What is the future for physical education in the 21st century? In Debates in physical education, eds. S. Capel., and M. Whitehead, 220-231. London: Routledge.

Kirk, D. 2010. Physical education futures. London: Routledge. 
Kirk, D. 1999. Embodying the school/schooling bodies: physical education as disciplinary technology. In The extra-ordinary school: Patergonality and pedagogy, eds. C. Symes., and D. Meadmore, 181-196. New York: Peter Lang.

Lave, J., and E. Wenger. 1991. Situated learning: Legitimate peripheral participation.

New York: Cambridge University Press.

Lincoln, Y.S., and E.G. Guba. 1985. Naturalistic Inquiry. London: Sage.

McCaughtry, N. 2006. Working politically amongst professional knowledge landscapes to implement gender-sensitive physical education reform. Physical Education and Sport Pedagogy 11 (2): 159-179.

McCaughtry, N., S. Sofo, I. Rovegno, and M. Curtner-Smith. 2004. Learning to teach sport education: misunderstandings, pedagogical difficulties, and resistance. European Physical Education Review, 10 (2): 135-156.

McLaughlin, M.W., and J. Zarrow. 2001. Teachers engaged in evidence-based reform: Trajectories of teacher's inquiry, analysis and action. In Teachers caught in the action. Professional development that matters, eds. A. Lieberman, and L. Miller, 79-101. New York: Teachers College Press.

Merriam, S.B. 1995. What can you tell from an $\mathrm{n}$ of 1 ? Issues of validity and reliability in qualitative research. PAACE Journal of Lifelong Learning 4: 51-60.

Morse, J. 1994. Emerging from the data: The cognitive processes of analysis in qualitative inquiry. In Critical issues in qualitative research methods, ed. J. Morse, 23-43. Thousand Oaks CA: Sage.

O’Donovan, T., A. MacPhail, and D. Kirk. 2012. Sustainable Sport Education in primary education: An English case study. In Sport Education: International perspectives, ed. P. Hastie, 15-29. Oxon: Routledge. 
O’Donovan, T., A. MacPhail, and D. Kirk. 2010. Active citizenship through sport education. Education 3-13 38 (3): 203-215.

O'Sullivan, M. 2007. Creating and sustaining communities of practice among physical education professionals. Physical Educator - Journal of Physical Education New Zealand 40 (1): 10-13.

Ovens, A., B. Dyson, and W. Smith. 2012. Implementing the Cooperative Learning model in physical education: the experience of New Zealand teachers. In Cooperative Learning in physical education, eds. B. Dyson, and A. Casey, 15-26. London: Routledge.

Parker, M., K. Patton, M. Madden, M, and C. Sinclair. 2010. From committee to community: the development and maintenance of a community of practice. Journal of Teaching in Physical Education 29: 337-357.

Patton, K., and L. Griffin. 2008. Experiences and Patterns of Change in a Physical Education Teacher Development Project. Journal of Teaching in Physical Education 27: 272-191.

Patton, K., and M. Parker. 2012. Moving from 'things to do on Monday' to student learning: physical education professional development facilitators' views of success. Physical Education and Sport Pedagogy I First Article. DOI: $10.1080 / 17408989.2012 .726980$

Patton, K., L.L. Griffin, D. Sheehy, R. Arnold, A.M. Gallo, K. Pagnano, P. Dodds, M.L. Henninger, and A. James. 2005. Navigating the mentoring process in a researchbased teacher development project: A situated learning perspective. Journal of Teaching in Physical Education, 24 (4): 302-325.

Phillips, D. K., and K. Carr. 2007. Illustrations of the analytic memo as reflexivity for preservice teachers. Educational Action Research 15 (4): 561-575 
Smith, A. 1759. The Theory of Moral Sentiments by Adam Smith, PART VII: Of Systems of Moral Philosophy Consisting of Four Sections Section IV: Of the Manner in which different Authors have treated of the practical Rules of Morality.

Sutherland, S. 2012. Borrowing strategies from adventure-based learning to enhance group processing in Cooperative Learning. In Cooperative learning in physical education: A research-based approach, eds. B. Dyson and A. Casey, 104-118. London: Routledge.

Tannehill, D. 2011. Professional learning in communities of practice. In Sport Pedagogy, ed. K. Armour, 312-324. London: Pearson.

Thompson, J. D. 1962. Organizations and output transactions. American Journal of Sociology 68 (3): 309-324.

Tinning, R. 2012. The idea of physical education: a memetic perspective. Physical Education and Sport Pedagogy 17 2: 115-126.

Tinning, R. 2010. Pedagogy and human movement. London: Routledge.

Wenger, E. 1998a. Communities of Practice; Learning, Meaning and Identity. UK: Cambridge University Press.

Wenger, E. 1998b. Communities of Practice: Learning as a Social System. Systems Thinker 9 (5): 1-10

Wenger, E., R.A. McDermott, and W. Snyder. 2002. Cultivating Communities of Practice: A Guide to Managing Knowledge. Perseus Books Group: Kindle Edition. 


\begin{tabular}{|c|c|}
\hline Data Source (Code used in paper) & Description \\
\hline 1. Field journal (FJ) & $\begin{array}{l}\text { Notes about informal discussions with } \\
\text { teachers and key incidences that took place } \\
\text { during Victoria’s time in the school. }\end{array}$ \\
\hline $\begin{array}{l}\text { 2. Post Lesson Teacher Analysis (PLTA) } \\
\text { (Dyson, 1994) }\end{array}$ & $\begin{array}{l}\text { Teachers responded to seven questions and } \\
\text { either wrote their answers on paper or } \\
\text { recorded them onto a voice recorder. }\end{array}$ \\
\hline 3. Post lesson interviews (PL Interview) & $\begin{array}{l}\text { Victoria interview the teachers after every } \\
\text { lesson observed. }\end{array}$ \\
\hline 4. Post Unit Interviews (PU Interviews) & $\begin{array}{l}\text { Victoria interviewed the teachers on the } \\
\text { completion of each unit. }\end{array}$ \\
\hline 5. Year End interviews (YE Interviews). & $\begin{array}{l}\text { An exit interview was undertaken with the } \\
\text { teachers at the end of the longitudinal } \\
\text { study. }\end{array}$ \\
\hline $\begin{array}{l}\text { 6. Cooperative Learning Validation Tool } \\
\text { (CLVT) (Casey, Goodyear and Dyson, In } \\
\text { Review) }\end{array}$ & $\begin{array}{l}\text { The first and last lesson of each unit were } \\
\text { video recorded. These recordings were then } \\
\text { systematically observed by Victoria using } \\
\text { the CLVT. This was used to support field } \\
\text { notes in ascertaining teacher and student } \\
\text { behaviours. }\end{array}$ \\
\hline 7. Professional Learning Meetings & $\begin{array}{l}\text { One professional learning meeting was } \\
\text { video recorded and transcribed. }\end{array}$ \\
\hline 8. Focus Group Interviews (FG Interviews) & $\begin{array}{l}\text { Victoria and the teachers also interviewed } \\
\text { the pupils at each of these time periods (i.e. } \\
\text { post lesson, post unit, and end of year). }\end{array}$ \\
\hline 9. Lesson observations (LO) & $\begin{array}{l}\text { Data were also used from lesson } \\
\text { observations conducted by senior leaders. }\end{array}$ \\
\hline $\begin{array}{l}\text { 10. Social Media and Web-Based } \\
\text { Discussions }\end{array}$ & $\begin{array}{l}\text { Data were collected from Facebook, } \\
\text { Twitter and a web-based discussion board. }\end{array}$ \\
\hline
\end{tabular}

Table 1: Data gathering tools 